\title{
THE LANDS WEST OF THE LAKES
}


For

Itut, Zalikah and sADIE 
V E R H A N D E L I N G E N VAN HET KONINKLIJK INSTITUUT VOOR TAAL-, LAND- EN VOLKENKUNDE

261

STEPHEN C. DRUCE

THE LANDS WEST OF THE LAKES

A history of the Ajattappareng kingdoms of South Sulawesi 1200 to 1600 CE

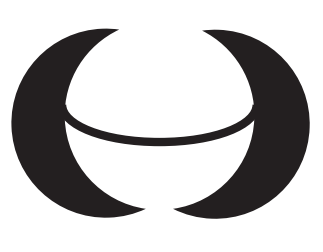

KITLV Press

Leiden

2009 
Published by:

KITLV Press

Koninklijk Instituut voor Taal-, Land- en Volkenkunde

(Royal Netherlands Institute of Southeast Asian and Caribbean Studies)

PO Box 9515

2300 RA Leiden

The Netherlands

website: www.kitlv.nl

e-mail: kitlvpress@kitlv.nl

KITLV is an institute of the Royal Netherlands Academy of Arts and Sciences (KNAW)

Cover: Creja ontwerpen, Leiderdorp

ISBN 9789067183314

(C) 2009 Koninklijk Instituut voor Taal-, Land- en Volkenkunde

No part of this publication may be reproduced or transmitted in any form or by any means, electronic or mechanical, including photocopy, recording, or any information storage and retrieval system, without permission from the copyright owner.

Printed in the Netherlands 


\section{Contents}

Figures, tables and photographs $\quad$ ix

Abbreviations $\quad$ xiii

Acknowledgements $\quad$ xv

System of transliteration and spelling conventions $\quad$ xvii

I Introduction $\quad 1$

Outline of the book 3

Sources and methods 5

Overview of South Sulawesi 13

The languages and people of South Sulawesi 17

The Ajattappareng kingdoms in South Sulawesi 23

Kingdoms, tributaries and domains: the political structure of the South Sulawesi kingdoms 26

The rise and development of the lowland South Sulawesi kingdoms: a theoretical perspective 32

II Oral and written tradition in South Sulawesi

Introduction 37

Oral tradition in South Sulawesi 40

The transmission of oral tradition 43

Transformation and functions of oral historical traditions 48

The written tradition 56

The origins of the written tradition 60

South Sulawesi writings of a historical nature 65

The attoriolong, patturioloang and pattodioloang texts 65

The chronicles 66

The relationship between oral and written traditions 72

Oral historical tradition in written form 74

Oral dissemination of the written word and the interaction between the oral and written registers 76

Stories about Suppaq, Sawitto and Gowa:

from the mid-sixteenth century to the twenty-first century 81

Tradition 1: The attoriolong Suppaq and Sawitto 81

Tradition 2: The fate of Wé Lampé Wéluaq and La Cellaq Mata 85

Tradition 3: Haji Paewa's tradition 86 
Tradition 4: A story from the oral register 89

Tradition 5: Modern print and oral dissemination of tradition 90

III A historical perspective on the geography and peoples of the Ajattappareng region

Introduction 91

The central lakes 92

The Saddang river system 100

The River Saddang 100

The evidence for the Saddang's change of course 103

Reconstruction of the former course of the Saddang river 112

The old Saddang delta 112

The Saddang-Sawitto branch 113

The Saddang-Tiroang branch 114

Pao to Sumpang Saddang 117

Causal factors for the Saddang's change of course 117

The relationship between rivers, trade and settlement patterns

in the Ajattappareng region before 1600118

The River Saddang 118

The Marauleng river 128

The Binagakaraeng river 131

The Bila river 133

The languages and people of the Ajattappareng region 135

Linguistic studies and local ethnolinguistic perceptions

in the Ajattappareng region 137

Bugis dialects of the Ajattappareng region 137

Massenrempulu languages of the Ajattappareng region 140

Pre-Islamic mortuary practice in the Ajattappareng region 143

Bugis and Makasar mortuary practices 143

Mortuary practices in the Ajattappareng region 146

Massenrempulu mortuary practices 147

A movement of people 151

Conclusion 157

IV Origin and precedence in Ajattappareng;

A historical perspective

Introduction 159

Austronesian ideas of origin and precedence 160

Origin and precedence in South Sulawesi 160

Rulers, commoners and blood 161

Precedence between settlements 164

Origin and precedence in Ajattappareng 166

An order of precedence among the Ajattappareng kingdoms 166

Written Ajattappareng genealogies 168

Origin traditions of individual kingdoms 174

The Sidénréng origin tradition 175

Traditions concerning Sawitto 180

Oral tradition from Simbuang 181 
Oral tradition form Kadokkong 184

Oral history from Sawitto 186

Oral tradition from Sawitto 188

Oral tradition from Cempa 195

An oral tradition from Alitta 198

Origin, precedence and history 198

V Ajattappareng, 1200 to 1600

Introduction 201

The rise of the Ajattappareng kingdoms:

archaeological evidence from the thirteenth and

fourteenth centuries 204

Early trade networks and the spread of wet-rice agriculture 213

The fifteenth century: expansion, alliance and agricultural intensification 214

The southward expansion of Suppaq and its emergence as a maritime power 215

The fifteenth century expansion of Sidénréng 220

Agricultural intensification in Rappang 223

Between the plains and the coast:

Alitta in the fifteenth century 225

The emergence of Sawitto 225

The sixteenth century 227

Conflict for control of the central plains and the defeat of Sidénréng 228

The emergence of a five-kingdom confederation 233

The maritime influence of Suppaq and Sawitto in the first

half of the sixteenth century 233

The first European visitors and conversion to Christianity 235

War with Gowa and the decline of Suppaq and Sawitto 241

Sidénréng's alliance with Gowa 245

Resistance to Gowa and the Islamization of Ajattappareng 246

VI Conclusion

Appendices

A The tributary and domain lists of Ajattappareng 255

B Archaeological survey data 265

C Transliterations and translations of lontaraq texts 311

D European maps from Chapter III 319

E Four European maps showing Durate 327

F List of informants 333

$\begin{array}{ll}\text { Glossary } & 337\end{array}$

$\begin{array}{ll}\text { Bibliography } & 341\end{array}$

$\begin{array}{ll}\text { Index } & 357\end{array}$ 
STEPHEN C , DRUCE - 9789004253827 Downloaded from Brill.comఠ4/26/2023 10:25:16AM via free access 


\section{Figures, tables and photographs}

Figures

1 Sulawesi in Indonesia 2

1.1 Provincial boundaries of Sulawesi 14

1.2 South Sulawesi kabupaten and kota madya boundaries 16

1.3 South Sulawesi language map 20

Satellite image of central Suppaq showing the extent of
destruction caused by fish and prawn farms

1.5 Geographical extent of Ajattappareng 26

2 Oral genealogy from Balusu 50

$\begin{array}{lll}2.1 & \text { First seven generations of the Soppéng genealogy } & 62\end{array}$

$\begin{array}{lll}2.2 & \text { Genealogy of Gowa } & 64\end{array}$

3 Manuel Pinto's estimate of the lake 95

3.1 Extent of flooding around lakes Tempe and Sidenreng 96

3.2 Small and large wet season floods around lakes Tempe, $\begin{array}{ll}\text { Sidenreng and Buaya } & 97\end{array}$

3.3 Pre-1600 archaeological sites in central Sidénréng 99

3.4 The present-day course of the River Saddang 101

3.5 Aubert's sketch map 104

3.6 1759 French map 106

\begin{tabular}{ll} 
3.7 & Late eighteenth-century Dutch map \\
\hline
\end{tabular}

$\begin{array}{lll}3.8 & 1842 \text { Dutch map } & 108\end{array}$

3.9 1848 Dutch map 109

$\begin{array}{ll}3.10 & 1854 \text { Dutch map }\end{array}$

3.11 1916-1917 Dutch map 111

3.12 Reconstruction of the Saddang's former course 119

$\begin{array}{ll}3.13 & \text { Settlements formerly connected by riverine navigation } \\ 3.14\end{array}$

3.14 Relationship between settlement patterns and the Saddang 124

$\begin{array}{ll}3.15 & \text { Centre of Sawitto } \\ 3.16 & 126\end{array}$

$\begin{array}{lll}3.16 & \text { Sawitto tributaries } & 127\end{array}$

$\begin{array}{ll}3.17 \text { Centre of Suppaq } & 130\end{array}$

3.18 Binagakaraeng river and the Tellu Lembang 133

$\begin{array}{ll}3.19 & \text { The Bila river } \\ 3.20 & 134\end{array}$

$\begin{array}{ll}3.20 & \text { Bugis dialect map } \\ 3.21 & 138\end{array}$

$\begin{array}{ll}3.21 & \text { Ajattappareng kecamatan boundaries } \\ 3.22 & 139\end{array}$

$\begin{array}{ll}3.22 & \text { Languages of Ajattappareng } \\ 3.23 & 144\end{array}$

3.23 Languages and topography of Ajattappareng 145 
3.24 Locations of pre-Islamic Massenrempulu burial sites 152

3.25 Proposed movement of people in Ajattappareng before 1600156

$4 \quad$ Genealogy of Sidénréng 170

$\begin{array}{lll}4.1 & \text { Genealogy of Suppaq } & 171\end{array}$

4.2 Genealogy of Sawitto 173

4.3 The eight original domain lands of Sidénréng 177

4.4 Location of the lands named in Lanting's tradition 182

$4.5 \quad$ Oral Kadokkong origin genealogy 186

4.6 Madimen origin tradition: Origin of the rulers of Sawitto 191

$\begin{array}{lll}4.7 & \text { Origin of the rulers of Sawitto } & 193\end{array}$

$\begin{array}{lll}4.8 & \text { The Cempa confederation } & 197\end{array}$

5 Central Suppaq archaeological sites $\quad 205$

5.1 Bacukiki, Soréang and Bojo 216

$\begin{array}{ll}5.2 & 219\end{array}$

5.3 Maiwa and its tributaries and domains 222

5.4 The estimated extent of Sidénréng's influence in
the fifteenth century

5.5 Identified toponyms named in the lasigalung tradition 236

A.1 The lands of the Sidénréng tributary and domain list 259

A.2 The lands of the Maiwa tributary and domain list 260

A.3 The lands of the Sawitto tributary and domain list 261

A.4 The lands of the Suppaq tributary and domain list 262

A.5 The lands of the Népo tributary and domain list 263

A.6 The lands of the Rappang tributary and domain list 264

Histograms of the distribution of classified ceramic sherds and period counts

B.1 Suppaq palace center, Makaraié, Matanré and Gucié 285

B.2 Indoq Lompa, Béla-bélawa, Tonrong Peppingé and Majennang 285

B.3 Alitta, Watang Sidénréng, Posiq Tana Sidénréng and Bulubangi 286

B.4 Wéngeng, Bélokka, Loloang and Sumpang Saddang 286

B.5 Total classified ceramic sherds recorded in Ajattappareng by century and half-century intervals

Standardized chronological histograms showing percentages of ceramic sherds recorded at each site by century and half-century intervals

B.6 Suppaq palace centre, Makaraié, Matanré and Gucié 287

B.7 Indoq Lompa, Béla-bélawa, Tonrong Peppingé and Majennang 288

B.8 Alitta, Watang Sidénréng, Posiq Tana Sidénréng and Bulubangi 288

B.9 Wéngeng, Bélokka, Loloang and Sumpang Saddang 289

B.10 Standardized chronological histogram showing percentages of total classified ceramic sherds recorded at Suppaq,

Alitta, Sidénréng and Sawitto

B.11 Standardized chronological histogram showing percentages of classified ceramic sherds recorded at surveyed sites in Suppaq 
B.12 Standardized chronological histogram showing percentages of classified ceramic sherds recorded at surveyed sites in Sidénréng

B.13 Suppaq palace centre, Makaraié and Indoq Lompa site map 291

B.14 Matanré site map 292

B.15 Béla-bélawa site map 293

B.16 Gucié site map 294

B.17 Tonrong Peppingé site map 295

B.18 Majennang, Marabombang and Lawaramparang site map 296

$\begin{array}{lll}\text { B.19 Alitta site map } & 297\end{array}$

B.20 Watang Sidénréng and Posiq Tana Sidénréng site map 298

$\begin{array}{ll}\text { B.21 Bulubangi site map } & 299\end{array}$

$\begin{array}{ll}\text { B.22 Wéngeng site map } & 300\end{array}$

$\begin{array}{ll}\text { B.23 Bélokka site map } & 301\end{array}$

$\begin{array}{ll}\text { B.24 Loloang site map } & 302\end{array}$

B.25 Sumpang Saddang site map 303

B.26 Bulu site map $\quad 304$

$\begin{array}{ll}\text { D.1 Aubert's sketch map } & 320\end{array}$

D.2 1759 French map 321

D.3 Late eighteenth-century Dutch map 322

D.4 1842 Dutch map 323

D.5 1848 Dutch map $\quad 324$

D.6 1854 Dutch map $\quad 325$

D.7 1916-1917 Dutch map 326

E.1 1611 Portuguese map $\quad 328$

$\begin{array}{lll}\text { E.2 } & 1619 \text { Dutch map } & 329\end{array}$

E.3 1633 Portuguese map $\quad 330$

E.4 1670 Dutch map 331

Tables

$1 \quad$ Kabupaten/kota madya size, population and density 17

$\begin{array}{lll}\text { B.1 Ceramic sherds recorded at Suppaq pre-Islamic palace centre } & 267\end{array}$

B.2 Ceramic sherds recorded at Makaraié 268

$\begin{array}{ll}\text { B.3 Ceramic sherds recorded at Matanré } & 270\end{array}$

B.4 Ceramic sherds recorded at Gucié $\quad 271$

$\begin{array}{ll}\text { B.5 Ceramic sherds recorded at Béla-bélawa } & 272\end{array}$

B.6 Ceramic sherds recorded at Indoq Lompa 273

$\begin{array}{ll}\text { B.7 Ceramic sherds recorded at Tonrong Peppingé } & 273\end{array}$

$\begin{array}{lll}\text { B.8 Ceramic sherds recorded at Majennang } & 274\end{array}$

B.9 Ceramic sherds recorded at Alitta $\quad 275$

B.10 Ceramic sherds recorded at Watang Sidénréng 277

B.11 Ceramic sherds recorded at Posiq Tana Sidénréng 278

$\begin{array}{ll}\text { B.12 Ceramic sherds recorded at Bulubangi } & 279\end{array}$

B.13 Ceramic sherds recorded at Wéngeng 280

$\begin{array}{ll}\text { B.14 Ceramic sherds recorded at Bélokka } 281 & 280\end{array}$

B.15 Ceramic sherds recorded at Loloang 283

B.16 Ceramic sherds recorded at Sumpang Saddang 284 


\section{Photographs}

$1 \quad$ Keramat at Wéngeng (Sidénréng domain land) 8

2 Broken martavans at Bulu, kabupaten Pinrang 11

3 Two broken martavans containing cremated remains at Bulu, kabupaten Pinrang

$4 \quad$ Haji Abu Bakar (owner, left) and Abdul Kadir with the palm-leaf lontaraq Balusu $\quad 38$

$5 \quad$ The lontaraq Balusu 58

6 Palm-leaf lontaraq from Padakalawa, kabupaten Pinrang 59

$7 \quad$ The channel between Lake Tempe and Lake Sidenreng (end of dry season) 94

$8 \quad$ The old Saddang-Sawitto river bed, Sekkang, kabupaten Pinrang 114

9 The bed of former Lake Alitta 117

10 The old river port of Rangaméa (the westerly, braided channel) 120

11 The modern-day port of Suppa 129

12 The Binagakaraeng river at Pajalele 132

13 Kalémpang, northern Sidrap 148

$14 \quad \begin{aligned} & \text { Partially exposed martavan containing cremated human } \\ & \text { remains, Malimpung }\end{aligned}$

15 Where the tomanurung of Kadokkong are believed to have descended

16 The baruga of a Sawitto noble, reminiscent of a Toraja tongkonan, Matiro Bulu, Pinrang $\quad 189$

17 The grave of Matjina, Cempa 196

18 Lawaramparang: where the first ruler of Suppaq is 208

19 Foot from a fourteenth-century Yuan incense burner found at Loloang 209

20 Selection of Thai, Vietnamese and Chinese sherds found at Puang Pitué, Manuba

21 Vietnamese sherds found in the Gucié survey 305

22 Ming Sancai sherds found in the Alitta survey 305

23 Yuan martavan sherds found in the Watang Sidénréng survey 306

24 Dehua sherds found in the Watang Sidénréng survey 306

25 Jizhou sherds found in the Bélokka survey 307

26 The survey team at Makaraié 307

27 Tonrong Peppingé 308

28 Loloang 308

29 Wéngeng 309 


\section{Abbreviations}

aSS attoriolong Suppaq and Sawitto

ANRIM Makassar branch of the Indonesian National Archives Bugis language B. Bugis

CE Common Era

cf. confer

CKA manuscript copied by Cassakka

E. Enrekang language

HP manuscript written by Haji Paewa

KITLV Royal Netherlands Institute of Southeast Asian and Caribbean Studies

M. Makasar language

Ma. Maiwa language

Mal. Malimpung language

NBG Nederlands Bijbelgenootschap

Sidrap Sidenreng-Rappang

TS. Toraja-Saddan language

UNHAS Hasanuddin University 
STEPHEN C , DRUCE - 9789004253827 Downloaded from Brill.comఠ4/26/2023 10:25:16AM via free access 


\section{Acknowledgements}

This book would not have been possible without the help, support and encouragement provided by many people. First I wish to thank Ian Caldwell, who was my supervisor at the Centre for South-East Asian Studies, Hull University, where this book began as a doctoral thesis. I am grateful for his constant support, advice and constructive criticism on both thesis and book. I also thank those lecturers at the Centre who taught me as an undergraduate. Thanks also to David Bulbeck for his detailed and constructive comments on the manuscript and for advice on my archaeological survey data. Campbell Macknight provided encouragement and advice, and identified a rare Yuan period incense burner foot from photographs while I was carrying out fieldwork in South Sulawesi. I also thank Terry King and Heather Sutherland for their comments on the manuscript. Raquel Losekann and Ricardo Tomaz provided assistance with Portuguese language sources.

In South Sulawesi I have many debts. I thank Puang Muhammad and Mustari, whose house in Lapalopo, Pinrang, I used as a base from which to carry out much of my fieldwork. I am indebted to Puang Muhammad and Mustari, their children, Sawedi, Suma, Sia and Ompe, for the generous hospitality and good company they afforded me on each occasion I stayed with them.

In Lapalopo I met Alimuddin, who accompanied me on many occasions during the early stages of fieldwork in Pinrang. His knowledge of Pinrang and its people and languages proved to be of great value. Abunawas and his family of Lautang Salo in Suppaq also deserve special mention. Abu's interest in my research made trips to Suppaq all the more enjoyable. I am very grateful to him and his family for their hospitality, not just on the many times that I stayed with them, but also for housing and feeding my archaeological survey team. Other people in South Sulawesi I wish to thank for their hospitality are: Iwan Sumantri and Muli, Budi and family, Bampe and Yammi, Mulianti and family, Jamaluddin and family, Suri and Mira, Maesar and family, Puwattiro and Muhammad Nasir and family. I also thank Haris, Adi, Kumare, Bahrir Haffid, Ote, Abu, Muhlis and Andi Rijaya for accompanying me at various times during fieldwork.

I express my deepest gratitude to all those people who told oral traditions 
to me or provided historical data. Their information is crucial to this book. The names of these informants are set out in Appendix F.

Muhlis Hadrawi, who first taught me to read Bugis manuscript texts when I was an undergraduate at Hasanuddin University (UNHAS), assisted me in transcribing and translating Bugis texts and accompanied me on a trip to Népo. Muhammad Salim also gave assistance and advice in transcribing and translating Bugis texts and provided several photocopies of manuscripts. I also thank Haji Djirong Basang for checking my understanding and interpretation of several sections of the Gowa chronicle.

I thank my archaeological survey team, who consisted of Karaeng Demanari, Irfan Mahmud, Muhammad Nur, Mansjur and Hamsa. They laboured tirelessly in difficult conditions and provided many fruitful discussions on my research.

I would like to thank the Economic and Social Research Council in the United Kingdom for their financial support, the Lembaga Ilmu Pengetahuan Indonesia for sponsoring my research, and Edward Poelinggomang of UNHAS for kindly agreeing to act as my sponsor in South Sulawesi.

I am also grateful to the staff of the following institutions who allowed me to access their collections: the Makassar branch of the Arsip Nasional Indonesia, the Universiteits Bibliotheek and the Koninklijk Instituut voor Taal-, Land- en Volkenkunde in Leiden, Hull University Library, Cambridge University Library, the British Library, Hasanuddin University Library and the Yayasan Kebudayaan South Sulawesi. The Centre for Remote Imaging, Sensing and Processing (CRISP) at the National University of Singapore allowed me access to their image catalogue and I thank them for giving me permission to use the satellite image in Chapter I.

I also thank my parents, John and Glenda Druce, for their encouragement and support, and my family in Makassar for their hospitality.

Finally, I wish to thank my wife, Rachmawati, who provided help with French language sources and accompanied me on several occasions during fieldwork. She also provided constant support and encouragement.

The site maps in Appendix B were drawn up by Mansjur and me in Makassar and later digitized in the United Kingdom. All other figures, tables and photographs, unless otherwise stated, are entirely my own work 


\section{System of transliteration and spelling conventions}

This book presents Romanized transliterations and English translations of 15 manuscript texts written in the Bugis script. The system of transliteration I follow, with two exceptions, is that used by Caldwell (1988). This system is based on the one developed by Noorduyn (1955) from the work of Cense. The first of these modifications concerns the aksara $\dot{\sim}$ which is represented by the letter e. This distinguishes it from the aksara $\propto$ n which is presented as é. The second modification concerns the glottal stop, a common feature of the Bugis language but not represented by the Bugis script. This glottal stop is represented by the letter $q$.

These modifications are represented in the examples given below:

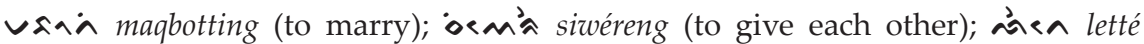

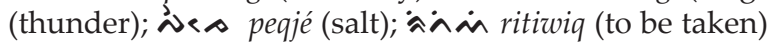

I have retained the glides, which are a common feature in Bugis manuscript texts, in the main body of the transliteration. This makes it possible to reproduce all the essential features of a Bugis text and enables its reproduction. Outside the transliteration, the glides are omitted in order to avoid inconsistent spelling.

These conventions, where applicable, are applied to words derived from other South Sulawesi languages that appear in the main text. The language each word belongs to is indicated as follows: B. Bugis; E. Enrekang; M. Makasar; Ma. Maiwa; Mal. Malimpung; TS. Toraja-Saddan. Bahasa Indonesia and European languages are unmarked.

I have used these spelling conventions for historical place names but not the names of modern administrative units or topographical features. For example, the kingdom of Suppaq, kecamatan (subdistrict) Suppa; the kingdom of Énrékang, kabupaten (regency) Enrekang; the kingdom of Sidénréng, Lake Sidenreng. The spelling of South Sulawesi language names follows conventions used by linguists, as found in Grimes (2000). 